\title{
THE EFFECT OF IMMERSION OF MANGROVE Avicennia alba (Tomlinson, 1986) LEAF EXTRACT WITH DIFFERENT CONCENTRATIONS IN PREVENTING BACTERIAL DISEASE Vibrio harveyi (Johnson \& Shunk, 1936) IN VANAME SHRIMP (Litopenaeus vannamei) (Boone, 1931)
}

\section{Eka Nur Farida*1, Rara Diantari, Esti Harpeni, Wardiyanto, Qadar Hasani, Herman Yulianto, Maulid Wahid Yusuf, Oktora Susanti*2}

\begin{abstract}
Vibriosis is a disease that often attack shrimp culture, some of the most dangerous types of Vibrio bacteria are $\underline{V}$. harveyi. The use of natural materials is an alternative that can be applied to prevent bacterial disease. One of the mangrove

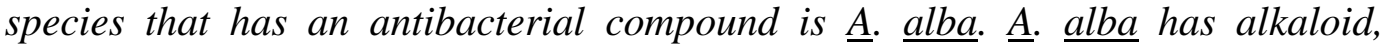
saponins, and flavonoids compounds that can inhibit the function of cytoplasmic membranes and energy metabolism in bacteria. This study was conducted to determine the effectiveness of $\underline{A}$. alba leaf extract $\underline{A}$. alba in inhibiting $\underline{V}$. harveyi disease in vaname shrimp (Litopenaeus vannamei). This research was conducted in several stages, namely extraction of mangrove leaves, both in vivo and in vitro. The highest SR, RPS and MTD values were obtamed at a concentration of $250 \mathrm{mg} / \mathrm{l}$ with each value of $80 \%, 60 \%, 75^{\text {th }}$ respectively hour. Mangrove leaf extract $\underline{A}$. alba was able to prevent diseases caused by the bacteria $\underline{V}$. harveyi, with the best results at an extract concentration of $250 \mathrm{mg} / \mathrm{l}$ where the concentration can significantly higher $S R, R P S$, and MTD compared to other treatments.
\end{abstract}

Keywords: $\underline{A}$. alba leaf extract, $\underline{V} . \underline{\text { harveyi }}, \underline{\text { Litopenaeus }} \underline{\text { vannamei }}$

\section{Pendahuluan}

Serangan penyakit pada udang vaname dapat terjadi mulai dari pembenihan hingga pembesaran. Penyakit merupakan masalah utama yang belum teratasi hingga sekarang (Septiani et al., 2016). Penyakit yang sering timbul pada budidaya udang yaitu penyakit Vibriosis.

Penyakit Vibriosis merupakan penyakit yang mudah timbul pada budidaya udang. Penyakit Vibriosis sering menyebabkan kerugian baik pada fase pembenihan maupun pembesaran, akibat kematian yang ditimbulkan (Kharisma et al., 2012). Salah satu jenis bakteri Vibrio, yang sering menyerang budidaya udang adalah $V$. harveyi (Kannapiran et al., 2009). Bakteri V. harveyi adalah bakteri gram negatif dan bakteri yang bersifat oportunistik, yaitu organisme yang dalam keadaan normal ada di

\footnotetext{
${ }^{1}$ E-mail: faridaeka94@yahoo.com

${ }^{2}$ Jurusan Perikanan dan Kelautan, Fakultas Pertanian, Universitas Lampung

Jl. Prof. S. Brodjonegoro No.1 Gedong Meneng Bandar Lampung, 35145
} 
lingkungan pemeliharaan, yang berkembang menjadi patogen apabila kondisi lingkungan dan inangnya memburuk (Widanarni et al., 2012).

Salah satu upaya dalam pencegahan penyakit udang adalah melalui peningkatan sistem pertahanan tubuh udang (Johny et al., 2005). Udang memiliki daya tahan tubuh alami yang bersifat non spesifik terhadap organisme patogen berupa pertahanan fisik (mekanik), kimia, seluler, dan humoral. Sistem imun udang tergantung pada proses pertahanan non spesifik sebagai pertahanan terhadap infeksi (Lee et al., 2004).

Penggunaan bahan alami merupakan salah satu alternatif yang dapat digunakan dalam peningkatan sistem imun dan juga sebagai antibakteri pada udang salah satunya tanaman mangrove. Salah satu spesies mangrove yang dapat meningkatkan sistem imun dan sebagai senyawa antibakteri yaitu $A$. alba. diketahui bahwa bagian daun A. alba. memiliki senyawa saponin, tannin, dan steroid (Handayani, 2012).

Oleh karena itu penelitian ini dilakukan untuk mengetahui efektivitas ekstrak daun mangrove $A$. alba dalam menghambat penyakit $V$. harveyi pada udang vaname (Litopenaeus vannamei).

\section{Metode}

\section{Ekstraksi Daun Mangrove}

Daun mengrove diperoleh dari Pulau Pasaran, Kecamatan Teluk Betung Barat, Bandar Lampung. Proses ekstraksi dilakukan menurut (Cendrianti et al., 2013) dengan mencuci daun mangrove A. alba., lalu dikeringkan, kemudian ditimbang sebanyak 100 gr dan dihaluskan. Selanjutnya daun dimasukkan kedalam erlenmeyer dan dimaserasi menggunakan metanol $70 \%$ selama 24 jam. Kemudian disaring menggunakan kertas saring. Selanjutnya proses ekstraksi dilanjutkan dengan menggunakan Vacuum Rotary Evaporatror (Buchi type) pada suhu $37^{\circ} \mathrm{C}(15,36 \mathrm{~g})$.

\section{Penyediaan Bakteri $\underline{\text { V. harveyi }}$}

Bakteri $V$. harveyi dikultur dengan menggunakan media NB (Merck No, 12000000-KIM000061548) dan di shaker selama 24 jam kemudian diukur menggunakan spektrofotometer (Thermo scientific Genesys 20) dengan panjang gelombang $625 \mathrm{~nm}$ hingga kepadatan bakteri $10^{7} \mathrm{CFU} / \mathrm{ml}$.

\section{Uji In Vitro}

Uji in vitro dilakukan dengan uji antibakteri atau uji daya hambat dengan metode (agar disc diffusion method) menurut Davis et al., (1971). Dosis ekstrak yang digunakan dalam uji in vitro yaitu 150, 200, 250, 300 dan $350 \mathrm{mg} / \mathrm{l}$. Media yang digunakan dalam uji antibakteri yaitu media NA (Merck no. 12000000-KIM000061548).

Bakteri $V$. harveyi dengan kepadatan $10^{7} \mathrm{CFU} / \mathrm{ml}$ dimasukkan kedalam cawan petri yang berisi media padat NA sebanyak $20 \mu \mathrm{l}$ dan diratakan menggunakan spreader, kemudian kertas cakram yang sebelumnya telah disterilisasi diberi larutan metanol untuk kontrol (-), antibiotik Chloramphenicol $250 \mathrm{mg}$ (SANBE-Bandung) untuk kontrol $(+)$, dan ekstrak daun mangrove dengan dosis 150, 200, 250, 300, dan $350 \mathrm{mg} / \mathrm{l}$. kertas cakram diletakkan 
kedalam media yang telah berisi bakteri $V$. harveyi dan diinkubasi selama 24 jam dan 48 jam selanjutnya diukur zona hambat yang terbentuk menggunkan jangka sorong.

\section{Percobaan Utama}

Percobaan utama atau Uji In Vivo dilakukan pada udang dengan ukuran 10 gr. Udang di budidaya dalam akuarium dengan ukuran $60 \mathrm{x}$ $40 \mathrm{x} 50 \mathrm{~cm}$. Penelitian ini menggunakan 5 perlakuan dengan 3 ulangan, perlakuan yang digunakan yaitu $\mathrm{K}+$ (tidak diberi ekstrak daun mangrove $A$. alba., namun di uji tantang dengan menggunakan bakteri $V$. harveyi), K- (tidak diberi ekstrak daun mangrove A. alba, dan diuji tantang dengan larutan PBS), serta 3 dosis terbaik esktrak daun mangrove A. alba., yang didapat dari uji antibakteri yaitu 150, 250, dan 350 $\mathrm{mg} / \mathrm{l}$. Udang uji terlebih dahulu di aklimatisasi selama 7 hari, kemudian direndam dengan menggunkan ekstrak daun mangrove A. alba. dengan konsentrasi yang telah didapat dari uji in vitro yaitu 150,250 , dan $350 \mathrm{mg} / \mathrm{l}$ selama 15 menit kemudian dipelihara selama 7 hari. Selanjutnya udang diuji tantang menggunakan bakteri $V$. harveyi dengan kepadatan $10^{7} \mathrm{CFU} / \mathrm{ml}$ melalu injeksi secara intramoskular, kemudian dipelihara selama 7 hari.

Selama pemeliharaan udang uji, pemberian pakan dilakukan selama 4 kali sehari secara ad satiation pada kisaran pukul 06.30 - 07.00, $11.30-$ $12.00,16.30$ - 17.00, dan $21.30-$ 22.00 dan dilakukan penyiponan setiap harinya untuk membuang sisa pakan dan kotoran serta pergantian air dilakukan setiap harinya setelah penyiponan sebesar $10 \%$ dari volume dalam air.

\section{Parameter Penelitian}

Parameter penelitian yang akan diamati yaitu Survival Rate (SR) mengacu pada (Effendi, 1979), Relative Percent Survival (RPS) mengacu pada (Ellis, 1988), Mean To Date (MTD) mengacu pada (OIE, 2004), dan kualitas air.

\section{Analisis Statistik}

Parameter Survival Rate (SR), Mean To Date (MTD) akan diamati dengan menggunakan uji ANOVA dengan selang kepercayaan 95\%, kemudian diuji lanjut menggunakan uji Duncan. Relative Percent Survival (RPS) akan dianalisis dengan menggunakan uji T. Parameter kualitas air diamati secara deskriptif.

\section{Hasil dan Pembahasan}

\section{SR ( $\underline{\text { Survival }}$ Rate) \\ Pada penelitian ini} kelangsungan hidup udang vaname pada konsentrasi $250 \mathrm{mg} / \mathrm{l}$ dan $\mathrm{K}$ memiliki nilai kelulus hidupan tertinggi yaitu $80 \%$, dan nilai kelangsungan hidup terendah pada $\mathrm{K}+$ yang tidak diberi perlakuan perendaman namun diuji tantang dengan menggunakan bakteri $V$. harveyi dengan nilai SR sebesar $60 \%$ (Gambar, 1).

Dari hasil uji statistik terhadap nilai SR pada udang vaname yaitu berbeda nyata $(\mathrm{P}<0,05)$. Hasil uji lanjut duncan konsentrasi $150 \mathrm{mg} / \mathrm{l}$, $250 \mathrm{mg} / \mathrm{l}, 350 \mathrm{mg} / \mathrm{l}$ dan $\mathrm{K}$ - tidak berbeda nyata namun berbeda nyata dengan perlakuan $\mathrm{K}+$. Nilai SR udang vaname pada perlakuan $\mathrm{K}+$ lebih rendah dibandingkan dengan 
perlakuan yang telah diberi ekstrak daun mangrove $A$. alba. Hal ini dikarenakan pada uji antibakteri yang telah dilakukan terbentuk zona hambat disekitar kertas cakram yang telah diberikan ekstrak daun mangrove A. alba. Artinya ekstrak tersebut mampu menghambat pertumbuhan bakteri $V$. harveyi.

Senyawa aktif yang terdapat pada ekstrak daun mangrove $A$. alba yang diduga mampu menghambat pertumbuhan bakteri $V$. harveyi sehingga mampu meningkatkan nilai SR. Senyawa-senyawa yang terdapat pada daun $A$. alba yaitu saponin, steroid dan tannin.

Senyawa saponin sebagai antibakteri yaitu dapat menyebabkan kebocoran protein pada enzim dari dalam sel bakteri Porphyromonas gingivalis (Madduluri et al., 2011). Senyawa saponin merupakan zat aktif yang dapat meningkatkan permeabilitas membran sehingga terjadi hemolisis pada sel. Senyawa saponin jika berinteraksi dengan sel bakteri, bakteri tersebut akan pecah atau lisis (Poeloengan et al, 2012).

Steroid dapat menyebabkan kebocoran pada lisosom bakteri (Madduluri et al, 2011). Steroid dapat berinteraksi dengan membran fosfolipid sel yang bersifat permeabel terhadap senyawa-senyawa lipofilik sehingga menyebabkan integritas membran menurun serta morfologi membran sel berubah menyababkan sel rapuh dan lisis.

Senyawa tannin memiliki mekanisme kerja sebagai antibakteri dengan cara menghambat enzim reverse transcriptase dan DNA topoisomerase sehingga sel bakteri tidak dapat terbentuk (Nuria et al., 2009).

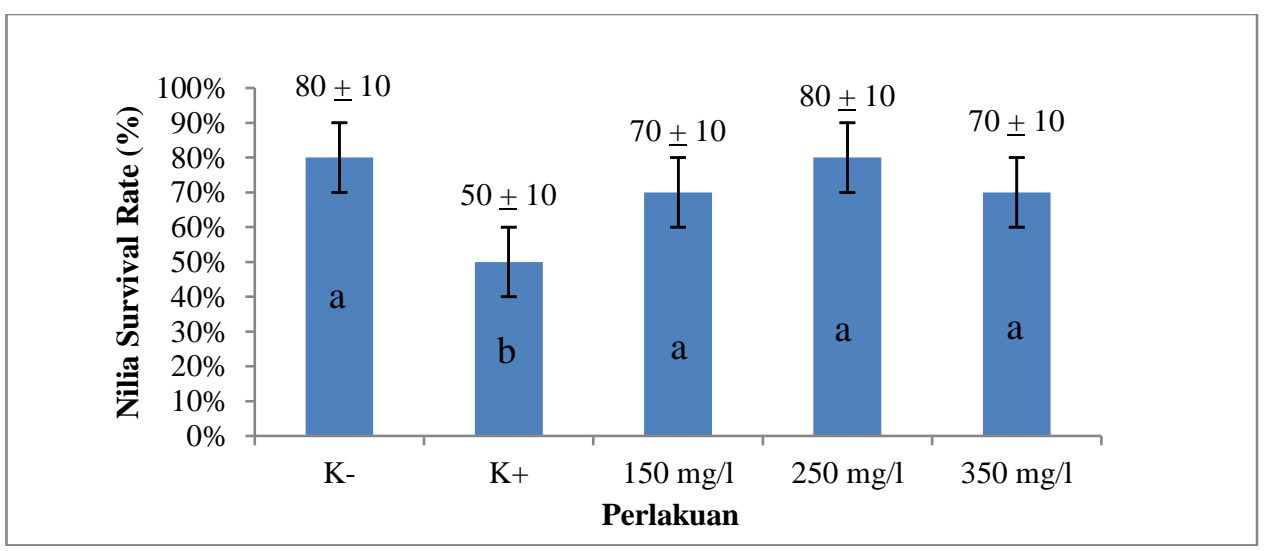

Gambar 1. Kelangsungan hidup (SR) udang vaname (Litopenaeus vannamei)

RPS (Relative Percent Survival)

Nilai RPS tertinggi pada konsentrasi $250 \mathrm{mg} / \mathrm{l}$ yaitu sebesar $60 \%$, dimana konsentrasi $250 \mathrm{mg} / \mathrm{l}$ memiliki mortalitas udang terendah, sedangkan konsentrasi $150 \mathrm{mg} / \mathrm{l}$ dan 350mg/l memiliki nilai RPS sebesar 40\%. Dari hasil uji statistik dengan menggunakan uji $\mathrm{T}$ nilai signifikan konsentrasi $150 \mathrm{mg} / \mathrm{l}, 250 \mathrm{mg} / \mathrm{l}$ dan $350 \mathrm{mg} / \mathrm{l}>0,05$ sehingga tidak ada pengaruh atau berbeda nyata antara perlakuan dengan konsentrasi esktrak yang diberikan.

Penggunaan ekstrak daun mangrove A. alba. dengan konsentrasi $250 \quad \mathrm{mg} / \mathrm{l}$ mampu memberikan perlindungan lebih baik 
sebesar $60 \%$ terhadap infeksi bakteri $V$. harveyi dibandingkan dengan konsentrasi $150 \mathrm{mg} / \mathrm{l}$ dan $350 \mathrm{mg} / \mathrm{l}$ yang hanya mampu melindungi udang dari serangan bakteri $V$. harveyi (Gambar 2). Hal ini sesuai dengan penelitian Parenregi et al., (2013) perlakuan dianggap efektif jika nilai RPS $>50 \%$.
Nilai RPS dipengaruhi oleh respon imun, semakin meningkatnya respon imun maka RPS akan meningkat (Rahmawati, 2017). Semakin rendah nilai RPS maka semakin kecil kemampuan sinbiotik untuk melindungi udang vaname dari infeksi $V$. harveyi.

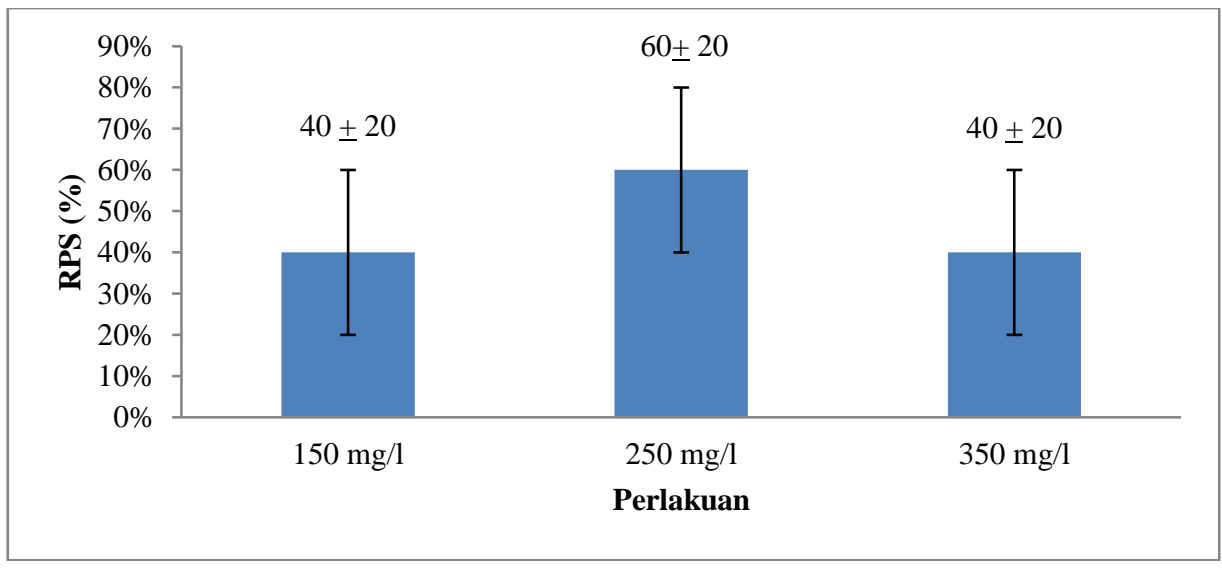

Gambar 2. Relative Percent Survival (RPS) udang vaname (Litopenaeus vannamei)

MTD (Mean Time to Death)

Hasil perhitungan MTD (rerata waktu kematian) setelah uji tantang selama 7 hari waktu kematian pada udang paling cepat pada perlakuan $\mathrm{K}+$ yaitu jam ke- 34 , waktu kematian udang paling lama pada perlakuan dengan konsentrasi $250 \mathrm{mg} / \mathrm{l}$ yaitu jam ke- 75 (Gambar 3). Dari hasil uji statistik terhadap nilai MTD pada udang vaname (Litopenaeus vannamei) berbeda nyata $(\mathrm{P}<0,05)$. Dari hasil uji lanjut konsentrasi 150 $\mathrm{mg} / \mathrm{l}, 250 \mathrm{mg} / \mathrm{l}$ dan $350 \mathrm{mg} / \mathrm{l}$ tidak berbeda nyata namun berbeda nyata dengan perlakuan $\mathrm{K}+$.

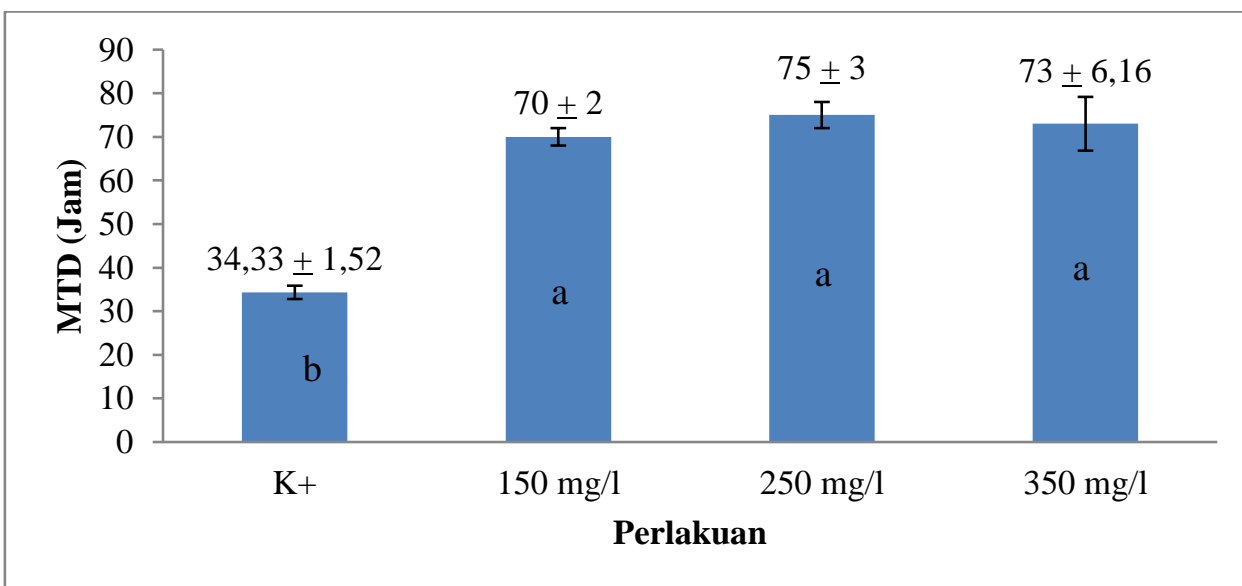

Gambar 3. Mean Time to Death (MTD) udang vaname (Litopenaeus vannamei) 
Ekstrak daun mangrove A. alba efektif dalam mencegah serangan bakteri $V$. harveyi pada udang vaname, dibuktikan dengan waktu kematian udang yang telah diberikan ekstrak daun A. alba 2 kali lipat lebih lama dibandingkan udang yang tidak diberi ekstrak daun mangrove $A$. Alba. Waktu kematian paling lama yaitu pada perlakuan $250 \mathrm{mg} / \mathrm{l}$. Sesuai dengan hasil RPS yang didapat konsentrasi $250 \mathrm{mg} / \mathrm{l}$ paling efektif dalammencegah serangan bakteri $V$. harveyi, karena menurut Parenregi et al., (2013), perlakuan dianggap efektif jika nilai RPS > 50\%.

Pengolahan kualitas air dilakukan dengan penyiponan dan pergantian air setiap hari selama penelitian. Berdasarkan hasil uji kualitas air yang telah dilakukan sesuai dengan SNI (01-7246-2006) dan masih dalam kisaran optimum, untuk nilai suhu $28-32{ }^{\circ} \mathrm{C}, \mathrm{pH} 7,5-$ 8,5, DO minimal 4, dan salinitas 28 32 ppt. Kualitas air yang optimum dalam budidaya udang vaname dengan suhu $28-32{ }^{\circ} \mathrm{C}, \mathrm{pH} 7,5-8,5$ (Haliman et al., 2008), DO $4-6$, dan salinitas 28 - 32 ppt (Rusmiyati, 2012). Dengan demikian parameter kualitas air selama pemeliharaan dalam kondisi optimum untuk budidaya udang vaname.

Menurut Haliman et al. (2008), kualitas air yang baik akan mendukung pertumbuhan dan perkembangan udang vanamei secara optimal. Sehingga penyebab kematian udang bukan disebabkan faktor kualitas air namun kematian udang disebabkan oleh faktor penunjang kelangsungan hidup dan ketahanan udang vaname.

\section{Kesimpulan}

\begin{abstract}
Kesimpulan dari penelitian ini yaitu ekstrak daun mangrove Avicenniai alba mampu mencegah penyakit yang disebabkan oleh bakteri $V$. harveyi, dengan hasil paling baik pada konsentrasi ekstrak $250 \mathrm{mg} / \mathrm{l}$ dimana konsentrasi tersebut dapat meningkatkan Survival Rate (SR), Main Time to Date (MTD), dan Relative Percent Survival (RPS) paling tinggi dibandingkan dengan perlakuan yang lain.
\end{abstract}

\section{Daftar Pustaka}

Cendrianti, F., Siti, M., \& Evi, U.U. 2013. Uji Aktivitas Ekstrak NHeksana, Etil Asetat, dan Etanol 70\% Daun Tempuyung (Sonchus arvensis L.) pada Mencit Jantan Hiperurisemia. Artikel Ilmiah Hasil Penelitian Mahasiswa. Fakultas Farmasi, Universitas Jember, Jember.

Davis, W., \& Strout, T. 1971. Disc methode of microbiological antibiotic assay. Aplled Microbiology, 22 (4): 59 - 73.

Effendie, M.I. 1979. Metode Biologi Perikanan. Gramedia Pustaka Utama, Jakarta.

Ellis, A.E. (Ed.). 1988. Fish vaccination (No. 4). Academic Press, London.

Haliman, R.W. dan S.D. Adijaya. 2008. Udang vannamei. Penebar Swadaya, Jakarta, 75 hlm

Handayani, E. 2012. Prevalensi Infeksi Bakteri Patogen pada Ikan Patin (Pangasius hypophthalmus) di Kawasan Minapolitan Kabupaten Banjar. Tesis. Sekolah Pasca Sarjana, Institut Pertanian Bogor, Bogor. 
Johny, F., Roza, D.K., Mahardika, Zafran, \& Prijono, A. 2005. Penggunaan Immunostimulan Untuk Meningkatkan Kekebalan Nonspesifik Benih Ikan kerapu Lumpur, Epinephelus coiodes Terhadap infeksi Virus irido. Jurnal Penelitian Perikanan Indonesia, 11(5): 75 - 83.

Kannapiran, E., Ravindran, J., Chandrasekar, R., \& Kalalarasi, A. 2009. Studies on luminous, $V$. harveyi Associated with Shrimp Culture System Rearing Penaeus monodon. J. Environ. Biol, 30(5): $791-795$.

Kharisma, A., \& Manan, A. 2012. Kelimpahan Bakteri Vibrio sp. Pada Air Pembesaran Udang Vannamei (Litopenaeus vannamei) sebagai Deteksi Dini Serangan Penyakit Vibriosis. Jurnal Ilmiah Perikanan dan Kelautan, 4(2): 129 - 134.

Lee, M.H. \& Shiau, S.Y. 2004. Vitamin E Requirements of Juvenil Grass Shirmp, P. monodon and effects on Nonspecific Immune Responses. Fish and Shellfish immunology, 16: 475 485.

Madduluri, S., Rao, K.B., \& Sitaram, B. 2013. In vitro evaluation of antibacterial activity of five indigenous plants extract against five bacterial pathogens of human. International Journal of Pharmacy and Pharmaceutical Science, 5(4): $679-684$.

Nuria, M.C., \& Faizatun, A. 2009. Uji Aktivitas Antibakteri Ekstrak Etanol Daun Jarak Pagar (Jatropha curcas L) Terhadap Bakteri Staphylococcus aureus ATCC 25923, Escherichia coli ATCC 25922, dan Salmonella typhi
ATCC 1408. MEDIAGRO, 5(2): $26-37$.

OIE. 2004. Manual of diagnonostic tests and vaccines for terrestrial animals 5th ed., Chapter 2. 1. 15. Newcastle Disease, Newcastle.

Parenrengi, A., Tenriulo, A., \& Tampangallo, B.R. 2013. Uji tantang udang windu Penaeus monodon trans genis menggunakan bakteri patogen $V$. harveyi. Konferensi Akuakultur Indonesia. Balai Penelitian dan Pengembangan Budidaya Air Payau Maros, Sulawesi Selatan.

Poeloengan, M., \& Praptiwi, P. 2012. Uji aktivitas antibakteri ekstrak kulit buah manggis (Garcinia mangostana Linn). Media Litbang Kesehatan, 20(2): 65 - 69.

Prasad, R.N., Viswanathan, S., Devi, J.R., Nayak, V., Swetha, V.C., Archana, B.R., \& Rajkumar, J. 2008. Preliminary phytochemical screening and antimicrobial activity of Samanea saman. Journal of Medicinal Plants Research, 2(10): 268 - 270.

Rahmawati, E. 2017. Ketahanan Udang Vaname (Litopenaeus vannamei, Boone 1931) yang Diberi Probiotik Bacillus sp. D2.2 Terhadap infeksi Vibrio alginolyticus. Skripsi. Universitas Lampung, Bandar Lampung.

Rusmiyati, S. 2012. Menjala Rupiah Budidaya Udang Vannamei. Pustaka Baru, Yogyakarta, 162 hal.

Septiani, D.R. 2016. Uji kinetika dan aktivitas antibakteri dari bakteri biokontrol Bacillus sp. D2.2 pada salinitas dan $\mathrm{pH}$ yang berbeda. Skripsi. Universitas Lampung, Bandar Lampung. 
SNI. 2006. Produksi Udang Vanname

L. vannamei di Tambak dengan

Teknologi Intensif. Badan

Standarisasi Nasional: SNI-01-

7246-2006. Badan Standar

Nasional, Jakarta.

Widanarni, Noermala, J.I., \& Sukenda. 2014. Prebiotik, Probiotik, dan Sinbiotik untuk Mengendalikan Infeksi $V$. harveyi dan IMNV pada Udang Vanname. Jurnal Akuakultur Indonesia, 13(1): $11-20$. 